ENTREPRENEURSHIP AND SUSTAINABILITY ISSUES

ISSN 2345-0282 (online) http://jssidoi.org/jesi/

2020 Volume 7 Number 3 (March)

http://doi.org/10.9770/jesi.2020.7.3(52)
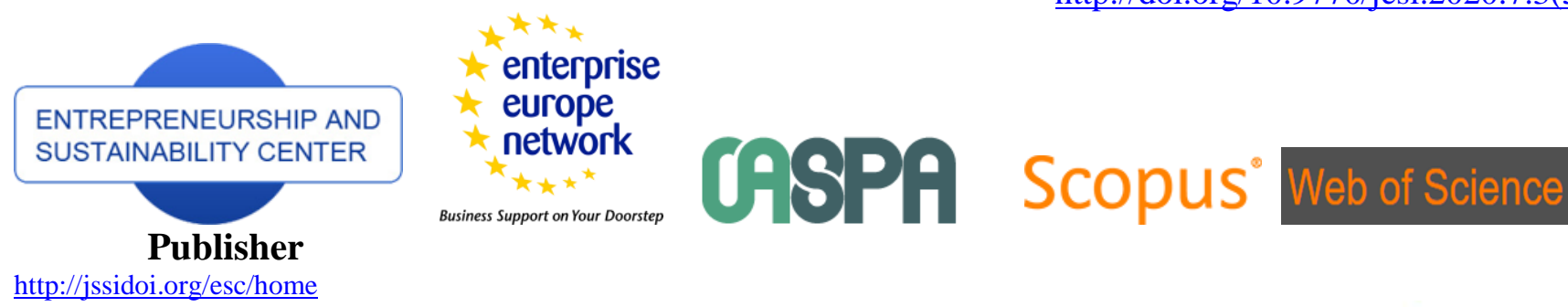

http://jssidoi.org/esc/home

\title{
ASSESSMENT OF THE FINANCIAL SECURITY OF INSURANCE COMPANIES IN THE ORGANIZATION OF INTERNAL CONTROL
}

\author{
Aksana A. Turgaeva ${ }^{1}$, Liudmila V. Kashirskaya*2, Yulia A. Zurnadzhyants ${ }^{3}$, \\ Olga A. Latysheva ${ }^{4}$, Irina V. Pustokhina ${ }^{5}$, Andrei V. Sevbitov ${ }^{6}$ \\ ${ }^{1}$ Astrakhan State technical university, 16, Tatischeva st., 414025, Astrakhan, Russian Federation \\ ${ }^{2}$ Financial University under the Government of the Russian Federation, Leningradsky Prospekt, 49, 125993, Moscow, \\ Russian Federation \\ ${ }^{3}$ Astrakhan State Medical University, Bakinskaya Street, 121, 414000, Astrakhan, Russian Federation \\ ${ }^{4}$ Altai State University, Lenin Ave., 61, 656049, Barnaul, Russian Federation \\ ${ }^{5}$ Plekhanov Russian University of Economics, Stremyanny lane, 36, 117997, Moscow, Russian Federation \\ ${ }^{6}$ Sechenov First Moscow State Medical University, 119991, Moscow, Trubetskaya st., 8-2, Russian Federation \\ E-mails:*2kashirskaya76@mail.ru (Corresponding author)
}

Received 20 June 2019; accepted 15 January 2020; published 30 March 2020

\begin{abstract}
The article is devoted to assessing the financial security of the activities of insurance companies as one of the stages in the implementation of all types of economic control and, in particular, internal control. The internal control of the business process connected with the assessment of financial security, with the assessment of risks in insurance companies at the present stage of economic development, is an urgent issue in the era of financial crises. Moreover, this area of internal control is not fully developed for practical use in insurance. The article provides an algorithm for assessing the financial security of an insurance company in internal control, and proposes a phased monitoring of the assessment of financial risks of an insurance company. Under the methodology of the study the following methods were taken: the methods of determinative factor analysis, an indicative method for determining the criteria for evaluating indicators. It is concluded that the need has arisen for using, as one of the sections of the methodology, the internal control of assessing the financial security of an insurance company. The result of the study was the development of an algorithm for conducting one of the sections of internal control using an assessment of the financial security of an insurance company. The practical significance of the article lies in the fact that conclusions and suggestions are aimed at developing modern economic control and contribute to real business optimization. A study conducted by the authors revealed that the new reality has changed the attitude towards the use of standard methods that do not take into account the particular functioning of companies, and requires the modernization of old ones and the introduction of new approaches to economic control methods.
\end{abstract}

Keywords: economic control; internal control; insurance company; financial security; risks; assessment

Reference to this paper should be made as follows: Turgaeva, A A., Kashirskaya, L.V., Zurnadzhyants, Yu. A., Latysheva, O.A., Pustokhina, I.V., Sevbitov A.V. (2020). Assessment of the financial security of insurance companies in the organization of internal control, Entrepreneurship and Sustainability Issues, 7(3), 2243-2254. http://doi.org/10.9770/jesi.2020.7.3(52)

JEL Classifications: M 41, M 42, M 49, G22.

Additional disciplines finances, audit. 


\section{ENTREPRENEURSHIP AND SUSTAINABILITY ISSUES}

ISSN 2345-0282 (online) http://jssidoi.org/jesi/

2020 Volume 7 Number 3 (March)

\section{Introduction}

http://doi.org/10.9770/jesi.2020.7.3(52)

The insurance sector of the economy at the new stage of its development is undergoing transformations associated with the application of economic control in its accounting and analytical activities. To a greater extent this is due to the transfer of insurance organizations to the category of public joint-stock companies. The activities of such business entities are regulated by the federal law of the Russian Federation (Federal Law of December 26, 1995 No. 208-FL). Public insurance organizations should disclose information in a wide format. To a greater extent, it benefits organizations themselves to increase the publicity of investment processes (Zhanbolatova et al., 2018; Vlasova et al., 2019; Akhmetshin, 2017). Since the public disclosure of information relates to the annual report of insurance organizations, annual financial statements, the organization of internal control is considered as an appropriate, complete and necessary process in the activities of an economic entity. With the introduction in 07/23/2013 of new article 28.1. "Internal control" in the Federal Law "About the organization of insurance in the Russian Federation", as well as article 19 of the Federal Law "About accounting" (About accounting. Article 19. Federal Law No. 402-FL, No. 50. - Art. 7344), conducting internal control in insurance companies becomes obligatory in its activities (Article 28.1. Federal Law No. 4015 -1 FL). According to information from the Ministry of Finance of the Russian Federation dated 12/26/2013 (Ministry of Finance of the Russian Federation, 2019), internal control must be applied at all levels of the economic entity and in all its divisions.

The organization of internal control in insurance companies should provide complete, reliable and objective information about financial statements, about assets and risks. Internal control should help counteract money laundering, lead to effective management of financial and economic activities, assets, risks, as well as ensure break-even and effective insurance operations (Salimova, 2016; Bench, 2016; Solonina et al., 2014; Chudaykina and Zhelikhovsky, 2019; Plaskova et al., 2019). Thus, internal control is a process that provides the economic entity with confidence in the safety of assets, achievement of high financial and operational indicators, accuracy in financial statements and its reliability, and it should also be aimed at achieving the goals of the company (Ministry of Finance of the Russian Federation, 2019). This definition can be taken as the basis for the goals of internal control of insurance companies. To achieve these goals, it is necessary to solve a number of problems associated with the specific activities of insurance companies (Goloshchapova et al., 2018; Da Costa, 2018; Sokolov et al., 2019). Therefore, the features of this field of activity require a special approach to organizing and conducting a modern, scientifically-based research process in the methodology of economic control, taking into account all the above aspects (Korableva et al., 2018).

\section{Methods}

The main objective of the activity of insurance companies is determined by the protection of the property rights of entities that have concluded an insurance contract in the event of an insurable event. The authors have repeatedly mentioned the risks of insurance companies in various works (Kuzovleva, 2015; Shatalova et al., 2016; Rahman, 2017; Turgaeva, 2015; 2017). The insurance business is directly related to the risks of policyholders, but the specificity of the insurance business is that as a commercial organization, insurance companies themselves take risks. These risks are associated with financial losses (for example, related to financial crises), inefficient investment (changes in the interest rate on securities), a high probability of losses, for example, due to fluctuations in the value of assets, and cumulative accumulation. The interpretation of the concept of financial security has been considered by many authors (Sushkova, 2019; But 2018; Vasilev, 2016; Eremeychuk and Mashyanova, 2016; Lobanov, 2018, 2019; Kozmenko and Ruban, 2014; Saenko et al., 2019; Prodanova et al., 2017; Bovsunovska, 2017; Trofimova et al., 2019; Yemelyanov et al., 2018; Bisultanova et al., 2018; Popova et al., 2017; Boboshko, 2017; Michailova et al., 2017; Masood et al., 2019; Vigliarolo, 2020; Chehabeddine, Tvaronavičienè, 2020)

Risks of insurance companies can be considered in various areas of activity, but since the scientific literature still does not address the issue of an internal control algorithm for assessing the financial security of an insurance 
company, we consider it appropriate to develop such an algorithm that will allow any insurance company to properly evaluate its own financial security.

\section{Results}

An assessment of the financial security of the activities of insurance companies as one of the stages in the implementation of all types of economic control, and, in particular, internal control, should include the following steps and consist of seventeen sequential actions aimed at a comprehensive analysis of indicators and threats to financial security (Fig. 1).

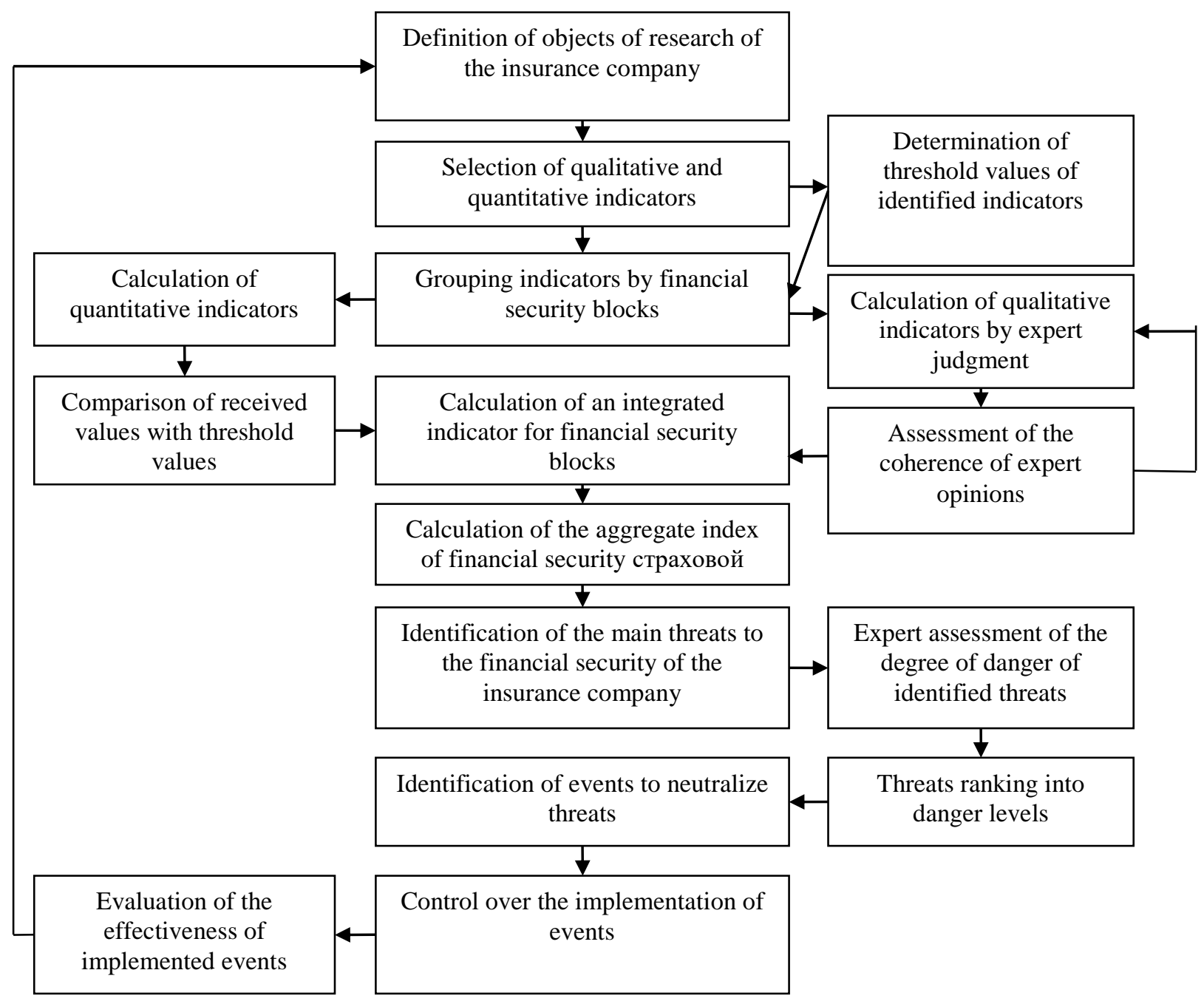

Fig. 1. The internal control algorithm for assessing the financial security of an insurance company Source: own research

1st stage. It consists in determining the objects under study of the financial security of the insurance company. In other words, this is the collection and systematization of the necessary company information, such as financial statements, a report on financial results, annual reports of departments of the insurance company, etc., the data of which will be used to calculate indicators. 
ENTREPRENEURSHIP AND SUSTAINABILITY ISSUES

ISSN 2345-0282 (online) http://jssidoi.org/jesi/

2020 Volume 7 Number 3 (March)

http://doi.org/10.9770/jesi.2020.7.3(52)

2nd stage. It consists in the selection of qualitative and quantitative indicators for assessing the financial security of an insurance company. Most quantitative indicators are widely used to assess the financial security of an organization (enterprise) of any economic field. However, it is worthwhile to include in the regulation of the internal control process a list of quantitative indicators and those that will allow you to assess the financial condition of the characteristics of the financial activities of the organization. As for the qualitative indicators, these indicators will help determine the frequency of payments, insurance premiums, as well as costs of litigation. They are also aimed at identifying fraudulent agreements in the company's activities, determining the impact of risks on insurance activities in general. Table 1 shows the main quantitative and qualitative indicators for assessing the financial security of an insurance company.

Table 1. Qualitative and quantitative indicators for assessing the financial security of an insurance company

\begin{tabular}{|c|c|c|c|c|}
\hline № s/i & Quantitative indicators & Threshold value & Qualitative indicators & $\begin{array}{l}\text { Threshold } \\
\text { value }\end{array}$ \\
\hline 1 & Current liquidity ratio & $1,5-2$ & $\begin{array}{l}\text { Qualitative dynamics of the company's } \\
\text { insurance reserves }\end{array}$ & Increment \\
\hline 2 & Absolute liquidity ratio & $0,2-0,3$ & $\begin{array}{l}\text { The frequency of insurance payments of } \\
\text { the company under insurance contracts }\end{array}$ & Moderately \\
\hline 3 & Financial independence ratio & $>0,5$ & $\begin{array}{l}\text { Frequency of expenses of litigation } \\
\text { cases (including those by type of } \\
\text { insurance) }\end{array}$ & Rarely \\
\hline 4 & Capital adequacy ratio & $>0,1$ & $\begin{array}{l}\text { Company integrity assessment of } \\
\text { insurance premium payments }\end{array}$ & Fixed payments \\
\hline 5 & Financial stability ratio & $>0,7$ & $\begin{array}{l}\text { The degree of influence of risks on the } \\
\text { activities of the insurance company }\end{array}$ & Minimally exposed \\
\hline 6 & Leverage ratio & $<1$ & $\begin{array}{l}\text { Frequency of conclusion of insurance } \\
\text { contracts per month }\end{array}$ & Often \\
\hline 7 & Receivable turnover ratio & $>15$ & $\begin{array}{l}\text { Level of attracted insurance clients } \\
\text { (including those by type of insurance) }\end{array}$ & High \\
\hline 8 & Profitability of assets & $>0,10$ & $\begin{array}{l}\text { Percentage of fraudulent contracts } \\
\text { concluded per year }\end{array}$ & Minimal \\
\hline 9 & Profitability of equity & $>0,15$ & Rating assigned by rating agencies & Top-10 \\
\hline 10 & $\begin{array}{lll}\begin{array}{l}\text { Profitability of insurance } \\
\text { operations }\end{array} & \\
\end{array}$ & $>0,12$ & & \\
\hline 11 & $\begin{array}{l}\text { The level of insurance payments } \\
\text { by type of insurance }\end{array}$ & $>0,6$ & & \\
\hline 12 & $\begin{array}{l}\text { Percentage of reinsurers in } \\
\text { insurance reserves }\end{array}$ & $0,05-0,3$ & & \\
\hline 13 & $\begin{array}{l}\text { The ratio of change in the } \\
\text { volume of insurance premiums } \\
\text { (including those by type of } \\
\text { insurance) }\end{array}$ & $1,0-1,1$ & & \\
\hline 14 & Moving loss ratio & $>0,65$ & & \\
\hline
\end{tabular}

As can be seen from table 1 above, for a comprehensive assessment of financial security, multidirectional indicators are proposed, with the help of which it is possible to assess the financial security of any insurance company. However, it is worth noting that this list of indicators is not exhaustive.

3rd stage. Defining threshold values for selected indicators of assessing the financial security of the insurance company. In most cases, the threshold values of these quantitative indicators are scientifically fixed. As for the specific quantitative and qualitative insurance indicators of the company, in this case, table 1 shows the estimated threshold values for insurance companies. However, as noted above, insurance companies themselves have the right to set their own threshold values based on the specifics of their insurance activities. 
4th stage. Grouping of selected indicators by blocks of financial security indicators. Since a wide range of financial security indicators is proposed, it is suggested to distribute the above indicators into blocks for ease of calculation. We propose to separate quantitative indicators (Table 2).

Table 2. Grouping indicators by financial security blocks

\begin{tabular}{|c|c|c|}
\hline № s/i & The title of the indicators & The title of the block \\
\hline 1 & Current liquidity ratio & \multirow{2}{*}{$\begin{array}{l}\text { Indicators of insurance } \\
\text { company liquidity ratios }\end{array}$} \\
\hline 2 & Absolute liquidity ratio & \\
\hline 3 & Financial independence ratio & \multirow{5}{*}{$\begin{array}{l}\text { Indicators of financial } \\
\text { stability of the insurance } \\
\text { company }\end{array}$} \\
\hline 4 & Capital adequacy ratio & \\
\hline 5 & Financial stability ratio & \\
\hline 6 & Leverage ratio & \\
\hline 7 & Moving loss ratio & \\
\hline 8 & Profitability of assets & \multirow{3}{*}{$\begin{array}{l}\text { Indicators of insurance } \\
\text { company profitability ratios }\end{array}$} \\
\hline 9 & Profitability of equity & \\
\hline 10 & Profitability of insurance operations & \\
\hline 11 & The level of insurance payments by type of insurance & \multirow{3}{*}{$\begin{array}{l}\text { Indicators of insurance } \\
\text { company payments }\end{array}$} \\
\hline 12 & $\begin{array}{l}\text { The ratio of change in the volume of insurance premiums (including those by type of } \\
\text { insurance) }\end{array}$ & \\
\hline 13 & The frequency of insurance payments of the company under insurance contracts & \\
\hline 14 & Receivable turnover ratio & \multirow{3}{*}{$\begin{array}{l}\text { Rating indicators of insurers } \\
\text { of an insurance company }\end{array}$} \\
\hline 15 & Company integrity assessment of insurance premium payments & \\
\hline 16 & Level of attracted insurance clients (including those by type of insurance) & \\
\hline 17 & $\begin{array}{l}\text { Frequency of conclusion of insurance contracts per month including those by type of } \\
\text { insurance) }\end{array}$ & \multirow[t]{2}{*}{$\begin{array}{l}\text { Rating indicators of insurers } \\
\text { of an insurance company }\end{array}$} \\
\hline 18 & Percentage of fraudulent contracts concluded per year & \\
\hline 19 & Percentage of reinsurers in insurance reserves & \multirow{2}{*}{$\begin{array}{l}\text { Indicators of insurance } \\
\text { reserve ratios }\end{array}$} \\
\hline 20 & Qualitative dynamics of the company's insurance reserves & \\
\hline 21 & Frequency of expenses of litigation cases (including those by type of insurance) & $\begin{array}{l}\text { Insurance company expense } \\
\text { indicators }\end{array}$ \\
\hline 22 & The degree of influence of risks on the activities of the insurance company & $\begin{array}{lll}\text { Insurance company } & \text { risk } \\
\text { indicators }\end{array}$ \\
\hline 23 & Rating assigned by rating agencies & Other indicators \\
\hline
\end{tabular}

Source: own research

It is also worth noting that this stage of diagnostics of the financial security of the insurance company will allow to evaluate the financial security of a particular block of indicators.

$5^{\text {th }}$ stage. Calculation of quantitative indicators of the financial security of an insurance company. Comparison of actual data with threshold values. At this stage of assessing the financial security of the insurance company, quantitative indicators are calculated both for the studied financial year and for previous periods to further compare the dynamics of the financial security of the insurance company.

$6^{\text {th }}$ stage. Correlation of actual indicators with threshold values. This stage is necessary for further calculation of the integrated indicators of financial security. The ratio of financial security indicators of the insurance company with their threshold values is determined as follows according to formula 1:

$$
\mathrm{Pfb}_{\mathrm{i}}=\mathrm{K}_{\mathrm{iact}} / \mathrm{K}_{\text {inorm }}
$$

where $\mathrm{Pfb}_{\mathrm{i}}-$ the value of the $\mathrm{i}$-th indicator of financial security of the insurance company; 
$\mathrm{K}_{\mathrm{iact}}$ - the actual value of the i-th indicator of financial security of the insurance company;

$\mathrm{K}_{\text {inorm }} \quad$ - threshold value of the $\mathrm{i}$-th indicator of financial security of the insurance company.

For convenience, the obtained values are entered in the table with the calculations.

$7^{\text {th }}$ stage. Calculation of qualitative indicators of the financial security of an insurance company through expert judgment. A group of experts evaluates qualitative indicators according to the available information about the financial activities of the insurance company. To each value of the qualitative indicator, experts give their mark in points on a 4-point scale. The scores obtained are compared with the threshold values of qualitative indicators in the same way as quantitative indicators.

$8^{\text {th }}$ stage. Assessment of consistency of expert opinion. Consistency of expert opinion is considered an important characteristic of the quality of the results of non-quantitative indicators.

It is recommended to calculate the consistency in terms of the Kendall concordance coefficient noted by Kuzovleva (2015. P.29). It looks as follows according to formula 2:

$$
\mathrm{W}=12 * \mathrm{~S} /\left[\mathrm{n}^{2} *\left(\mathrm{~m}^{3}-\mathrm{m}\right)\right]
$$

where $\mathrm{W}$ - coefficient of concordance of opinions of experts (by Kendall);

$\mathrm{S}$-the sum of the squared deviations of all rank estimates of each examination object from the arithmetic mean;

$\mathrm{n}$ - the number of experts;

$\mathrm{m}$-the number of examination objects.

We propose to draw up a table to calculate the assessment of expert consistency (Table 3).

Table 3. An example of the design of the table for calculating the assessment of expert consistency

\begin{tabular}{|c|c|c|c|c|c|c|c|c|}
\hline \multirow[b]{2}{*}{$\begin{array}{l}\text { № } \\
\text { s/i }\end{array}$} & \multirow[b]{2}{*}{ The title of the indicator } & \multicolumn{4}{|c|}{ Expert Score } & \multirow[b]{2}{*}{$\begin{array}{l}\text { Sum of ranks } \\
(\mathrm{clm} . \\
3+4+5+6)\end{array}$} & \multirow[b]{2}{*}{$\begin{array}{l}\text { Deviation from } \\
\text { the mean }\left(Q_{\text {mean }}-\right. \\
\text { clm.7) }\end{array}$} & \multirow[b]{2}{*}{$\begin{array}{l}\text { Deviation } \\
\text { squared }(\mathrm{clm} .8)^{2}\end{array}$} \\
\hline & & 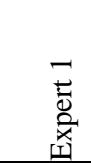 & 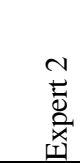 & 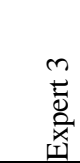 & 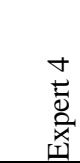 & & & \\
\hline 1 & 2 & 3 & 4 & 5 & 6 & 7 & 8 & 9 \\
\hline$\ldots$ & $\ldots$ & $\ldots$ & $\ldots$ & $\ldots$ & $\ldots$ & $\ldots$ & $\ldots$ & $\ldots$ \\
\hline $\mathrm{n}$ & $\operatorname{Sum}\left(\mathrm{Q}_{\text {mean }}\right)$ & - & - & - & - & & - & \\
\hline
\end{tabular}

The concordance coefficient varies in the range $0<\mathrm{W}<1$, where 0 corresponds to inconsistency, and 1 corresponds to complete consistency. If the concordance value exceeds $0.40-0.50$, then the quality of the assessment is considered satisfactory, if it exceeds or is equal to 0.70-0.80 - high.

If the result of assessing the consistency of expert opinions when calculating the qualitative indicators of the financial security of the insurance company exceeds satisfactory values, then it is necessary to proceed to stage 7 . If the consistency score is below average, then it is recommended that experts return to step 6 to recalculate the qualitative indicators.

$9^{\text {th }}$ stage. Calculation of integrated indicators for blocks of financial security indicators. The integrated mark of indicators of financial security of an insurance company is determined as follows by formula 3 :

$$
\text { Ifbn }=\sum \text { Pfb } 1+\text { Pfb2 }+ \text { Pfb3 } \ldots+\text { Pfbn } / \mathrm{n}
$$

где If $b_{n}$ - an integral mark of indicators of financial security of an insurance company; 


\section{ENTREPRENEURSHIP AND SUSTAINABILITY ISSUES}

ISSN 2345-0282 (online) http://jssidoi.org/jesi/

2020 Volume 7 Number 3 (March)

http://doi.org/10.9770/jesi.2020.7.3(52)

$\sum \mathrm{Pfb}_{1}+\mathrm{Pfb}_{2}+\mathrm{Pfb}_{3} \ldots+\mathrm{Pfb}_{\mathrm{n}}-$ the amount of correlated indicators of the financial security of the insurance company with their threshold values;

$\mathrm{n}$ - The number of indicators

For convenience, the obtained values are entered in the table with the calculations. Already at this stage of assessing the financial security of the insurance company, it is possible to identify the "problem areas" of the financial activities of the insurance company.

$10^{\text {th }}$ stage. Calculation of an aggregate index of financial security of an insurance company. It looks as follows according to formula 4 :

$$
\mathrm{KFB}=\sum \mathrm{Ifb}_{1}+\mathrm{Ifb}_{2}+\mathrm{Ifb}_{3} \ldots+\mathrm{Ifb}_{\mathrm{n}}
$$

where KFB - aggregate index of financial security assessment of an insurance company;

$\sum \mathrm{Ifb}_{1}+\mathrm{Ifb}_{2}+\mathrm{Ifb}_{3} \ldots+\mathrm{Ifb}_{\mathrm{n}}-$ the sum of the values of the integrated marks of the financial security indicators of the insurance company.

If the insurance company assessed its financial security for several periods of time, then at this stage you can study the dynamics of changes in ensuring the financial security of the insurance company and suggest the reasons for such changes.

$11^{\text {th }}$ stage. Determining the level of financial security of the insurance company according to the identified aggregate index. At this stage of internal control, the level of financial security is determined on the basis of a defined scale of security levels (Table 4).

Table 4. Insurance Company Financial Security Level Scale

\begin{tabular}{|l|l|l|l|}
\hline Critical level & Low level & Average level & High level \\
\hline$>12$ & $12-23$ & $23-36$ & $<36$ \\
\hline
\end{tabular}

Source: own research

According to Table 4 above, the financial security of insurance companies is assessed at the following levels:

1) critical level (almost all indicators do not correspond to threshold values)

2) low level (most indicators do not correspond to threshold values);

3) average level (4-5 indicators do not correspond to threshold values);

4) high level (indicators correspond to threshold values; it is allowed that 2-3 indicators do not correspond to threshold values).

$12^{\text {th }}$ stage. Identification of the main threats to financial security according to a security assessment. Based on the assessment of the financial security of the insurance company, as well as the calculations of qualitative and quantitative indicators, the main threats to the financial security of the insurance company are identified. The list of these threats can also be classified according to various criteria for further convenience in determining measures to improve the financial security of the insurance company. These signs may appear (object of threat; frequency of manifestation of the threat; subject of the threat; source of occurrence, etc.).

$13^{\text {th }}$ stage. Expert assessment of identified threats. At this stage, it is recommended that a group of internal control auditors should conduct an assessment of identified threats using the Fine-Kinney method, which consists in assessing individual risks in any organization. This method includes the product of three components: impact, probability and consequences of the onset (formula 4). 
ENTREPRENEURSHIP AND SUSTAINABILITY ISSUES

ISSN 2345-0282 (online) http://jssidoi.org/jesi/

2020 Volume 7 Number 3 (March)

http://doi.org/10.9770/jesi.2020.7.3(52)

$$
\mathrm{R}_{\mathrm{i}}=\mathrm{P} * \mathrm{I} * \mathrm{~A}
$$

where $\mathrm{R}_{\mathrm{i}}$ - the value of the degree of danger of the $\mathrm{i}$-th threat of the company;

$\mathrm{P}$ - the probability of the occurense of the i-th threat;

I - Strength of the impact of the i-th threat on the security;

A - The consequences of the i-th threat.

Based on this method, Table 5 is presented below, which contains the necessary conditions for assessing threats to the financial security of an insurance company.

Table 5. Factors for assessing threats to the financial security of an insurance company

\begin{tabular}{|c|c|c|c|c|c|}
\hline Probability of a threat & Point & Impact on security & Point & Threat consequences & Point \\
\hline Most likely to happen & 10 & Extremely High Impact & 10 & Critical consequences & 10 \\
\hline Very likely & $8-9$ & High impact & $8-9$ & Serious consequences & $7-9$ \\
\hline Non relevant, but possible & $5-7$ & Moderate impact & $5-7$ & Moderate consequences & $4-6$ \\
\hline Unlikely & $2-4$ & Low impact & $2-4$ & Minor consequences & $1-3$ \\
\hline Hardly possible & $0-1$ & Extremely low impact & $0-1$ & & \\
\hline
\end{tabular}

Source: own research

For a more objective assessment of the degree of danger of the impact of threats on the financial security of the insurance company, it is recommended to conduct an expert assessment (Hilkevics and Semakina, 2019).

This method will help evaluate each threat in three directions: the probability of occurrence, the strength of the impact, and the consequences of the threat. Also, for the reliability of the opinions of experts at this stage, it is possible to assess the consistency of opinions of experts by the already known method.

14th stage. Threat ranking. The results of internal control at this stage of risk assessment rank them according to the degree of danger of identified threats to the financial security of the insurance company. This stage will help to further determine the priority areas of the insurance company to increase the level of financial security by neutralizing or minimizing the impact of identified threats.

15th stage. Identification of measures to neutralize threats. After determining the financial security assessment, identifying and assessing the main threats, effective measures are drawn up aimed at increasing the financial security of the insurance company, as well as at neutralizing or minimizing the impact of financial security threats. Also, at this stage, in addition to the events themselves, the following may be indicated: the expected economic effect for the insurance company from the implementation of these measures; deadline for the implementation of activities; responsible persons (departments) for the implementation of activities; supposed financing of events, etc.

16th stage. Internal control of the results of the implementation of measures to neutralize threats. Monitoring the implementation of measures to increase financial security presented by the insurance company is carried out not only by the head of the economic security service of the insurance company, but also by the heads of departments who are responsible for the implementation of a particular event. Upon completion of the deadlines for the implementation of measures, each department provides reports on the work done, on the basis of which the effectiveness of measures to improve the financial security of the insurance company will be evaluated.

17th stage. Assessment of the effectiveness of the implemented measures. As noted above, the assessment of the effectiveness of the measures taken is based on the information provided on the measures taken. At this stage, the insurance company itself determines the methods and methods convenient for it to conduct internal control of evaluating the effectiveness of the measures taken. If the activities are ineffective, it is recommended that you return 


\section{ENTREPRENEURSHIP AND SUSTAINABILITY ISSUES}

ISSN 2345-0282 (online) http://jssidoi.org/jesi/

2020 Volume 7 Number 3 (March)

http://doi.org/10.9770/jesi.2020.7.3(52)

to step 13 to determine new activities, taking into account the results obtained at this stage. If the measures taken have been effective, then a new assessment of the financial security of the insurance company is carried out again from the first stage.

\section{Discussion}

Despite all the complexity and painstaking work to identify certain aspects of financial security in the economic control system, the above internal control procedures not only optimize business processes at an early stage of their implementation, but also allow you to quickly make changes as a result of identifying various deviations, development of specific operational management recommendations for adjusting business processes (Luzina et al., 2019; Akhmetshin et al., 2019; Prodanova et al., 2019). Conducting the internal control of the business process related to the assessment of financial security, with the assessment of risks in insurance companies is relevant.

\section{Conclusions}

Thus, the presented algorithm for conducting internal control of the insurance company's financial security assessment will make it possible to comprehensively evaluate not only the main financial quantitative indicators of the insurance company, but also qualitative indicators, the degree of danger to financial security threats, the effectiveness of the proposed measures to increase the level of financial security of the insurance company. Such a mechanism of internal control will reveal the company's potential, strong and weak points, thereby making internal control more effective and useful to ensure the financial security of the insurance company.

\section{References}

About joint-stock companies: Federal Law of December 26, 1995 No. 208-FL (as amended). "Collected Acts of the Russian Federation Law". 01/01/1996. - No. 1.-Article 1

About accounting. Article 19. Internal control: federal law dated 06.12.2011 No. 402- FL (as amended). "Collected Acts of the Russian Federation Law." - 12.12.2011. - No. 50. - Art. 7344.

About the organization of insurance business in the Russian Federation. Article 28.1. Internal Control: Federal Law of November 27, 1992 No. 4015 -1 FL (as amended). Rossiyskaya Gazeta. - No. 6.- 12.01 .1993

Akhmetshin, E. M. (2017). The System of Internal Control as a Factor in the Integration of the Strategic and Innovation Dimensions of a Company's Development. Journal of Advanced Research in Law and Economics, 8(6), 1684-1692. https:// doi.org/10.14505/jarle.v8.6(28).03

Akhmetshin, E. M., Plaskova, N. S., Iusupova, I. I., Prodanova, N. A., Leontyev, A. N., \& Vasilev, V. L. (2019). Dataset for determining rational taxation value with incompatible criteria of economic efficiency and equity. Data in Brief, 26 https:// doi.org/10.1016/j.dib.2019.104532

Bench L.G. (2016). Insurance business: Textbook, 3rd ed., Ext. and reslave. - M.: SIC INFRA-M., 36.

Boboshko, N.M. (2017). Assessment of ensuring financial security of the insurance sector. Innovative development of the economy, 3 (39), 213.

Bisultanova, A. A., Zemlyakova, N. S., Razzhivin, O. A., Udovik, E. E., Adamenko, A. A. (2018). Modern trends in corporate finance management. Espacios, 39(31).

Bovsunovska H. (2017). The trends in the insurance market development in the context of ensuring the countrys economic security. Development economy, 3(83), 53-58. 


\section{ENTREPRENEURSHIP AND SUSTAINABILITY ISSUES}

ISSN 2345-0282 (online) http://jssidoi.org/jesi/

2020 Volume 7 Number 3 (March)

http://doi.org/10.9770/jesi.2020.7.3(52)

But T.P. (2018). Financial Security of an Insurance Company. Current Status and Prospects for the Development of the Insurance Market, 135.

Chehabeddine, M., Tvaronavičienė, M. (2020). Securing regional development. Insights into Regional Development, 2(1), 430-442. http://doi.org/10.9770/IRD.2020.2.1(3)

Chudaykina T.N., \& Zhelikhovsky D.O. (2019). Financial security as an in-house component of economic security. Alley of Science, 2 (29): 393.

Da Costa, G. F., Da Silva, D. O., \& Carneiro, W. J. (2019). Development and validation of analytical method to quantify the dissolution of cinarizin in capsules compounded. [Desenvolvimento e validação de método analítico para quantificar a dissolução de cinarizina em cápsulas magistrais] Periodico Tche Quimica, 16(31), 650-659.

Eremeychuk K.Yu., \& Mashyanova E.E. (2016). Financial stability of insurance companies in the financial security system of the Russian insurance market. Science Time, 10(34), 78.

Goloshchapova, L. V., Plaskova, N. S., Prodanova, N. A., Yusupova, S. Y., \& Pozdeeva, S. N. (2018). Analytical review of risks of loss of profits in cargo transportation. International Journal of Mechanical Engineering and Technology, 9(11), 1897-1902.

Hilkevics, S., Semakina, V. (2019). The classification and comparison of business ratios analysis methods. Insights into Regional Development, 1(1), 48-57. https://doi.org/10.9770/ird.2019.1.1(4)

Korableva, O. N., Kalimullina, O. V., \& Mityakova, V. N. (2018). Innovation activity data processing and aggregation based on ontological modelling. Paper presented at the 2018 4th International Conference on Information Management, ICIM 2018, 1-4. https:// doi.org/10.1109/INFOMAN.2018.8392659

Kozmenko S.M., \& Ruban O.O. (2014). Identification of the Level of Financial Security of an Insurance Company. Business inform, 2, 321-326.

Kuzovleva N.F. (2015). New approaches to assessing financial security in the insurance industry. Actual problems of the financial security of Russia, 29.

Lobanov S.Yu. (2019). Methods for ensuring financial security of the insurance company services market. Economics and modern management: theory, methodology, practice, 134 .

Lobanov S.Yu. (2018). Recommendations on the prevention of threats and ensuring the financial security of the insurance company services market. Innovations and Investments, 3, 318.

Luzina, T. V., Dudareva, E. A., Akhmetshin, E. M., Prodanova, N. A., Berdova, Y. S., \& Emaletdinova, G. E. (2019). International legal format for trans regionalisation of trade and economic partnership within BRICS in global development. Space and Culture, India, 7(3), 76-85. https://doi:10.20896/saci.v7i3.508

Masood, O., Tvaronavičienè, M., Javaria, K. (2019). Impact of oil prices on stock return: evidence from G7 countries, Insights into Regional Development 1(2): 129-137. https://doi.org/10.9770/ird.2019.1.2(4)

Michailova, Julija, Mačiulis, Alminas, Tvaronavičienè, Manuela. (2017). Overconfidence, risk aversion and individual financial decisions in experimental asset markets, Economic research = Ekonomska istraživanja, 30(1), 1119-1131. http://dx.doi.org/10.1080/1331677X.2017.1311234

Popova L.V., Balashova N.N., Dugina T.A., Gorshkova N.V., \& Turgaeva A.A. (2017). Ways of Increasing Innovative Activity in the Agrarian Sphere as a Basis of Food Security. Contributions to Economics, 9783319606958: 381 -386.

Prodanova, N. A., Smolentsev, V. M., Norkina, A. N., Shukshina, Y. A., \& Polyanskaya, O. A. (2017). Formation of system of internal control and features its functioning in the innovative development of industrial enterprises. International Journal of Applied Business and Economic Research, 15(13), 179-189.

Plaskova, N. S., Prodanova, N. A., Samusenko, A. S., Erzinkyan, E. A., Barmuta, K. A., \& Shichiyakh, R. A. (2019). Investment decisions formation: Innovative assets. International Journal of Engineering and Advanced Technology, 9(1), 2913-2916. https:// doi.org/10.35940/ijeat.A1213.109119 


\section{ENTREPRENEURSHIP AND SUSTAINABILITY ISSUES}

ISSN 2345-0282 (online) http://jssidoi.org/jesi/

2020 Volume 7 Number 3 (March)

http://doi.org/10.9770/jesi.2020.7.3(52)

Prodanova, N. A., Plaskova, N. S., Khamkhoeva, F. A., Yandiev, R. S., Serebryakova, T. Y., \& Ivanov, E. A. (2019). Methodological approaches for strategic economic analysis. International Journal of Economics and Business Administration, 7(3), 305-316.

Salimova G.A. (2016). Insurance fraud. Actual problems of the functioning of the financial mechanism of the regions, 394.

Rahman, P. A. (2017). Analysis of the mean time to data loss of nested disk arrays RAID-01 on basis of a specialized mathematical model. IOP Conference Series: Materials Science and Engineering, 177(1). https://doi.org/10.1088/1757-899X/177/1/012088

Saenko, N., Voronkova, O., Volk, M., \& Voroshilova, O. (2019). The social responsibility of a scientist: Philosophical aspect of contemporary discussions. Journal of Social Studies Education Research, 10(3), 332-345.

Shatalova, T. N., Chebykina, M. V., Zhirnova, T. V., \& Bobkova, E. Y. (2016). Controlling system as a key factor energy management of an industrial enterprise. International Review of Management and Marketing, 6(1), 7-12.

Sokolov, B., Potryasaev, S., Serova, E., Ipatov, Y., \& Andrianov, Y. (2019). Informative and formal description of structure dynamics control task of cyber-physical systems. Journal of Applied Engineering Science, 17(1), 61-64.

Solonina S.V., Ovsyanitsky E.S., \& Anufrieva A.N. (2014). Factors of ensuring financial stability and solvency of the insurance organization. Scientific journal, 99(05): 917.

Sushkova I.A. (2019). Financial security of the insurance industry: concepts, threats, methods of support. Economic security and quality, $1(34), 34$

The official website of the Ministry of Finance of the Russian Federation. "Organization and implementation by an economic entity of internal control of the facts of economic life, accounting and the preparation of accounting (financial) statements" [Electronic resource]. The electron.data. - [M., 2019.]. - Access mode: http://www.minfin.ru

Trofimova, L., Prodanova, N., Korshunova, L., Savina, N., Ulianova, N., Karpova, T., \& Shilova, L. (2019). Public sector entities' reporting and accounting information system. Journal of Advanced Research in Dynamical and Control Systems, 11(8 Special Issue), 416424.

Turgaeva A.A. (2017). Investment potential of insurance companies and assessment of their competitiveness. Finance and Credit. Publisher: LLC Publishing House Finance and Credit, 2(722): 89-109.

Turgaeva A.A. (2015). Management accounting in the insurance risk management information system. International Accounting, 24 (366): $46-56$

Vasilev, V. L. (2016). Control as an instrument of management and institution of economic security. Academy of Strategic Management Journal, 15(Special Issue 1), 1-7.

Vlasova, N. I., Kazakov, A. V., Kotova, X. Y., \& Ilyasov, R. H. (2019). Improving Management Functions at an Enterprise: Levels of the Internal Control System. Quality - Access to Success, 20(171), 39-43.

Yemelyanov, V., Tochilkina, T., Vasilieva, E., Nedelkin, A., \& Shved, E. (2018). Computer diagnostics of the torpedo ladle cars. Paper presented at the AIP Conference Proceedings, 2034 https:// doi.org/10.1063/1.5067351

Vigliarolo, F. (2020). Economic phenomenology: fundamentals, principles and definition. Insights into Regional Development, 2(1), 418429. http://doi.org/10.9770/IRD.2020.2.1(2)

Zhanbolatova, A., Zhumanov, K., \& Jumabekova, A. (2018). Relationship between bank competition and stability: The case of the UK. Banks and Bank Systems, 13(1), 98-114. https:// doi.org/10.21511/bbs.13(1).2018.10

Ziyadin, S. (2012). Effect of the world global economic crisis on the condition of banking systems. Actual Problems of Economics, 134(8), 419-429. 


\section{ENTREPRENEURSHIP AND SUSTAINABILITY ISSUES}

ISSN 2345-0282 (online) http://jssidoi.org/jesi/

2020 Volume 7 Number 3 (March)

http://doi.org/10.9770/jesi.2020.7.3(52)

\section{Aksana TURGAEVA}

Candidate of Economics, Assistant Professor, Assistant Professor of the Department «Economic security". Research interests - Control, economic security, financial security, risks, management accounting

ORCID ID: https://orcid.org/0000-0002-8374-1706

\section{Liudmila KASHIRSKAYA}

Professor, Doctor of the Economic Sciences, Financial University under the Government of the Russian Federation, Russia. Research interests - accounting expertise, state financial control, audit, departmental interaction, efficiency of activity.

ORCID ID: https://orcid.org/0000-0002-0234-0223

\section{Yulia ZURNADZHYANTS}

$\mathrm{PhD}$ in Economics, associate professor, of economics and health care management with postgraduate course, Astrakhan State Medical University. Expert in the theory of management of the health system, economic analysis of medical organizations and evaluation of their effectiveness. Research interests: economics, economic security in health care, economic analysis of medical organizations, efficiency assessment.

ORCID ID: https://orcid.org/0000-0002-7820-9918

\section{Olga LATYSHEVA}

Candidate of agricultural science, docent of the Faculty of Geography of Altai State University. Research interests: real estate valuation, financial security, insurance companies

ORCID ID: https://orcid.org/0000-0001-9279-1943

\section{Irina PUSTOKHINA}

Associate Professor, Entrepreneurship and Logistics Department, Plekhanov Russian University of Economics. Currently engaged in teaching economics and management disciplines at the Faculty of Marketing, Faculty of Trade Economics and Commodity Science and IBS-Plekhanov and research in the field of management, management control, logistics management, supply chain management, entrepreneurship and entrepreneurship education. Research interests: management, control, internal control systems, logistics, supply chain management, entrepreneurship, entrepreneurship training.

ORCID ID: https://orcid.org/0000-0001-5480-8871

\section{Andrei SEVBITOV}

Doctor of Medicine, Professor, Head of the Department of propaedeutics of dental diseases of the Institute of Dentistry of Sechenov University. Currently engaged in teaching dentistry, as well as conducts research in the field of team management, corporate reporting. Research interests: management in dentistry, internal control systems, implementation of financial plan performance indicators. ORCID ID: https://orcid.org/0000-0002-8247-3586

Register for an ORCID ID: https://orcid.org/register

Copyright (C) 2020 by author(s) and VsI Entrepreneurship and Sustainability Center

This work is licensed under the Creative Commons Attribution International License (CC BY).

http://creativecommons.org/licenses/by/4.0/

\section{c) (i) Open Access}

